\title{
The Portable Recording Studio: Documentary Filmmaking and Live Album Recording, 1967-1969
}

\author{
Landon Palmer \\ Indiana University \\ laapalm@indiana.edu
}

\begin{abstract}
While live performance and rock authenticity are topics widely investigated across popular music studies, cultural studies, and performance studies, the particular media practices that constitute liveness in rock music have been treated without rigorous historical specificity. Utilizing the concept of "fidelity" as it has developed within sound media scholarship as a means for historicizing the technological and cultural practices of sound recording, this article examines the construction of liveness through media objects produced via intersecting practices of documentary filmmaking and live album recording. By exploring the operations of filmmaking and sound recording in four live albums produced from North American rock music festivals between 1967 and 1969, this article not only highlights an overlooked history of the relationship between film and popular music recording, but also demonstrates how liveness, as an experiential category, is constituted through media practices not always exclusive to the conventional parameters of popular music industries.
\end{abstract}

KEYWORDS: live music, performance, sound recording, documentary cinema, fidelity 


\section{Introduction}

When documentary film director Michael Wadleigh and his crew of camera and sound technicians endeavoured to capture the Woodstock Music and Arts Festival in August 1969 for a feature film of the event, they arrived equipped with some of the most state-of-the-art portable media technologies available at the time. Moving images of musicians, festival attendees, and organizers were generated by the production's Éclair NPR 16mm film cameras, roughly twenty-pound devices "ergonomically suited to handheld operations" and equipped with a "quickchange magazine [that] minimized the exposure [to] airborne dust, sand and moisture", natural elements that pervaded the unpredictable setting of Wadleigh's outdoor shoot (Bell 1999: 21). Just as (if not more) important as this adaptable camera was the crew's mobile sound recording technologies. As summarized by Wadleigh's technical collaborator Charlie Peck, the Éclair camera "was designed to work with ... the Swiss-made Nagra III portable tape recorder", a "compact, rugged, precise" device capable of producing a sound Peck characterizes as "rich and pure" with "crystalline highs, gut-punching lows" resonating "almost as faithful as any recording studio at the time" (Bell 1999: 25). The crew's choice of sound recording technology evidently paid off in their production of a theatrical film event meant to reproduce the sensory experience of attending a major music festival. In fact, these audio recordings proved doubly useful, mixed for both the film Woodstock: Three Days of Peace and Music (Wadleigh 1970) and its successful soundtrack album.

Although Woodstock - one of the most widely seen documentaries in American film history - is likely the most obvious example, utilizing sound recordings made by documentary filmmakers for commercial live album releases became a regular practice during the late-1960s. These recordings were variously promoted as film soundtracks, live albums, or something in between. Each example in the following study features sound technicians, recording engineers, and documentary filmmakers capturing and packaging sounds in order to represent live events in the form of feature films and long-playing (LP) commercial records. Within the space of the music festival, emergent portable practices of sound recording and filmmaking converged in the interest of representing experiential qualities of the live performance. Such cross-industrial and transmedia practices were not always compatible or uniform in execution, and I detail two cases in which star musicians' interpretation of events in the form of a live album differed from and conflicted with that of filmmakers. However, the following cases altogether illustrate how practitioners of sound and moving image recording saw the credible and dynamic capture of the live event's experiential qualities as their goal and, in so doing, produced, echoed, and augmented dominant interpretations of particular music events. Such practices evince more than an intriguing historical overlap between conventions of nonfiction filmmaking and live album recording during the late 1960s. These practices emerged as the respective cultures of documentary cinema and rock music shared an investment in mobilizing media techniques towards preserving a sense of immediacy from events captured. The industrial and technological collaborations that produced live albums of rock festivals during the late 1960s were borne from 
cultural valuations and ideals compatible across nonfiction filmmaking and rock music.

Key scholarship in documentary film studies has addressed the historical importance of live rock music culture with respect to the nonfiction film practice commonly referred to as direct cinema (see: Beattie 2008; Kahana 2008; Saunders 2007). Similarly, works of scholarship in performance studies, cultural studies, and popular music studies have explored the essential yet contradictory roles of technology in authenticating live music performances (see: Auslander 2008; Frith 2007, 2010; Gracyk 1996; Théberge 1997). By examining the relationship between filmmaking and live album recording across four celebrated events in rock history - The Monterey International Pop Festival, The Woodstock Music and Art Fair, The Toronto Rock and Roll Revival, and the Rolling Stones' 1969 American tour - the following essay uses these case studies to argue for a more historically rigorous consideration of the technological, industrial, and cultural practices that inform the notion of "liveness" in popular music. This comparative media history of filmmaking and live album recording during late-1960s rock music festivals demonstrates that manifestations of liveness are not byproducts of a fixed or uniform value system, but are bound by historically and culturally specific media practices, even (or especially) during this zenith of North American live music culture. In so doing, this study illustrates how recording practices across filmmaking and rock music intersected in the pursuit of fidelity in representing the live event, a mediated production of an experience that participated in ideologies of authenticity associated with rock culture. By exploring technicians', engineers', and filmmakers' pursuits of fidelity in recording four widely publicized rock music festivals between 1967 and 1969, this article not only highlights an overlooked cross-industrial history of the relationship between filmmaking and popular music recording, but also demonstrates how liveness as an experiential category is constituted through specific media practices not always exclusive to the conventional parameters of popular music industries.

\section{Sound fidelity as media practice}

Within sound studies scholarship, fidelity as a critical concept has been approached as a means for understanding how a credible relation to the subject of sound recording is exhibited through aesthetic and technical qualities attributed to sound recording itself. Fidelity describes the potential for sound recording technologies to obscure the mediation between recording device and recorded subject via discursive ideals of technological development that seek to affectively erase the echoes of mediated representation. As observed by Rick Altman, representations of sound masquerade as reproductions of sound through claims to fidelity, thus making fidelity "a strange hybrid of engineers' aspirations and ideology, serving to mask recording's representational nature" (1992: 40). Writing about the emergence of sync-sound technologies in American cinema, James Lastra describes sound fidelity as "an effect of inscription", a technological practice that "sets as its goal the perfectly faithful reproduction of a spatiotemporally specific musical performance" (2000: 148, 139). Jonathan Sterne refers to sound technicians' pursuit of fidelity during the early twentieth century as 
an idealized "philosophy of mediation" in search of a "vanishing' mediator" (2003: 218). For the sound historian, fidelity is not a technical term or objective measure, but a discursive, ideological, and social phenomenon that illustrates sound recording's roles and uses within a mediated society and technology-driven culture. Claims to fidelity in sound recording are evidence of technology's historically specific meanings within culture, and variant discourses and practices of fidelity tell us more about historically specific relations between recording technologies and their uses than they reveal about some credible essence of a subject captured and reproduced through its encounter with such technologies.

In his history of how early twentieth-century sound recording devices were promoted through claims to fidelity in advertising, Sterne observes that, "sound reproduction - from its very beginnings - always implied social relations among people, machines, practices, and sounds. The very concept of sound fidelity is a result of this conceptual and practical labor" (2003: 219). When documentary filmmakers and sound recording engineers adopted new sound and moving image recording technologies to capture music festivals, they engaged in conceptual and practical labor that realized a particular manifestation of fidelity specific to the culture of rock music. These technicians' vocabulary may not match that of the advertisers and inventors in Sterne's study or the film sound engineers in Lastra's work, but their labor similarly speaks to the pursuit of a mediated relationship between event and listener paradoxically characterized by immediacy.

The moment in which the live recording microphone meets the sounds produced by musicians at music festivals is a moment in which rock music's and nonfiction filmmaking's respective industrial practices and emergent philosophies of media intersect. By incorporating this understanding of sound fidelity into theories of rock authenticity and liveness, I demonstrate that historically specific and cross-industrial practices of recording and reproduction materialized and participated in ideologies of live performance in late-1960s North American rock music. Furthermore, discourses of fidelity also perform a historicizing function in regards to particular music events. Whether in harmonic or dissonant relation to each other, concert documentaries and live albums have produced authoritative representations of concerts and canonized certain musical performances. Such recordings are made manifest through technicians' ideas of what constitutes a credible representation of the event's experiential qualities. By detailing how the content of concert films and live albums of this period was co-determined through arrangements and interactions between filmmakers, sound engineers, festival organizers, and rock stars, the following case studies illustrate how fidelity to live music performance is constructed in terms of the affective and experiential possibilities of sound recording, which informs sound and moving image media's historicization of events represented.

\section{Liveness, sound recording, and rock music}

Much of the history of late-1960s rock music has focused (understandably) on the recording studio as a space in which certain compositional features and musical ideas were explored through emergent technologies and recording practices 
(Gracyk 1996: 75). The Beach Boys' Pet Sounds (Capitol 1966), the Beatles' Sgt. Pepper's Lonely Hearts Club Band (Parlophone 1967), and other albums of this period saw musicians and producers approaching the recording studio as a musical medium, what Paul Théberge describes as "a compositional tool in its own right" made most evident during the "art mode" of popular music recording practiced between 1965 and 1970 (1997: 215-16, 219-21). ${ }^{1}$ Continued displays of cultural interest in such recording practices have not stopped at the valorization of the mid-to-late-60s work of the Beatles and the Beach Boys. As illustrated by recent documentaries including The Wrecking Crew (Tedesco 2008), Muscle Shoals (Camalier 2013), and Sound City (Grohl 2013), the popular history of rock music circuitously emphasizes the primacy of the recording studio as a site of technological and creative development and collaboration, fetishized through displays of recording technology that have, in the era of digital music, transformed into objects of nostalgia. ${ }^{2}$ Such regard for the recording studio was recently echoed in the promotional trailer for the PBS music documentary series Soundbreaking, which first circulated days after the death of celebrated Beatles producer George Martin, in which Ringo Starr describes the domain of celebrityproducers like Martin and Phil Spector as such: "The studio was a strange place full of crazy scientists, electricians, and madmen..." (Soundbreaking 2016).

Yet, until recently, for much of the history in which the recording studio served as an integral tool in the production, composition, and technological realization of rock music, there has existed what Theodor Gracyk describes as a "poverty of images documenting the experiences of musicians creating music in studios" (1996: 77). In contrast, the mid-to-late 1960s produced a bounty of images of musicians engaging in live performance outside the studio setting, whether in filmed concerts or the established pop platform of the television soundstage. ${ }^{3}$ The relationship of live and recorded music performance has thereby presented scholars a seemingly contradictory arena for navigating the ontology of rock. Although live touring has fluctuated in the importance of its role within rock music as a commercial industry (McKinna 2014: 56-57), scholars have argued to varying degrees that live performance has served as rock music's auratic site of ideological articulation, for live performance in effect displays a reversal of rock music's less widely represented processes of cultural production located in the recording studio.

While authenticity is a performative concept of musical identity realized through live music performance - summarized by Daniel R. McKinna as "a shared experience, knowledge and practice ... a common sense that enables us to identify what is 'true' regarding both who the artists is and the sincerity of their performance" (2014: 59) - it also bears a contradictory commodifying function. As stated by Gracyk,

What most of the concert audience forgets (or never acknowledges in the first place) is that the musicians are usually re-creating the music, not making it. What survives the transfer to live performance is the music's main stylistic features, supplemented by theatrics. (Gracyk 1996: 77, emphasis original)

Philip Auslander has echoed these claims in his conceptualization of liveness in rock, in which he argues that live performance serves "to authenticate the 
recording" of music performed without functioning "explicitly" in reference to it (2008: 91). The slippage, for Gracyk and Auslander, is of original and copy. Live performance is promoted and afforded importance as an encounter with the source (the musician and her/his virtuosic performance of music identified with them), yet the performance is shaped and evaluated in reference to the more fragmented process of musical production that already took place in the recording studio.

However, this intriguing conceptualization of the rock culture's construction of liveness through studio recording risks homogenizing what can be appealing about live performance to audiences, reiterating a rigid understanding of musical creativity as tied to the idea of compositional "originality", and overlooking the social component important to many live music experiences (see: Frith, Brennan, Cloonan and Webster 2013: ix; Toynbee 2000: 56). Rather than understanding how live performance displaces the originating cultural work of the recording studio, liveness - as one of many categories of relationships between musicians, technology, and audiences - can be better understood as a byproduct of sound recording itself. As Sarah Thornton explains, live became part of "the lexicon of music appreciation" during the 1950s as public relations campaigns were organized to contrast recording when it began to dominate the business of music and threaten the livelihood of working musicians (1996: 42-43, 51). By transforming into a general synonym for performed music, the term "live", Thornton argues, "soaked up the aesthetic and ethical connotations of life-versusdeath, human-versus-mechanical, creative-versus-imitative", with liveness positioned as a positive, valued, and overdetermined category in the face of seemingly interminable technological abstraction (1996: 43). In short, despite propagating some auratic essence of music performance, liveness is a byproduct of recording. This is true not only of the origins of liveness as a historically specific category of performance, but also of the media practices that communicate and reproduce liveness. If liveness and rock authenticity are contextualized as specific but hardly unprecedented inflections of larger historical practices of fidelity in sound recording, then live performance itself can be better understood as a phenomenon whose power is afforded by certain practices and modes of sound recording taking place both inside and outside the studio. ${ }^{4}$

By requiring a direct encounter between the sound technician and the performing musician in a concert space, documentary sound recordings of live music demonstrate how live musical performance is not predicated as much on a performative distance or erasure of sound recording and its concomitant associations with capitalist production, but is instead constituted through such processes. As instruments wielded by engineers, sound technicians, and filmmakers to communicate fidelity, portable sound recording technologies and remote recording techniques have augmented the experiential qualities of liveness - not unlike accompanying stage technologies such as amplifiers and lights - but in this case in service of the continued commodification of live music events. Even if we accept Gracyk and Auslander's postulation outright that live rock performances are essentially performances of recorded objects, then concert albums and documentaries continue the work of the music industry by staging the reverse: they display the power of live performance as the originating source of a 
recorded object, offering an encapsulation of the immediacy and presence associated with the live experience through the capacities of recording technologies.

That live events have served as the groundwork for reproduction practices beneficial to the music industry is further evinced by several key performers and groups - including Janis Joplin, Jimi Hendrix, and Crosby, Stills and Nash - who exploded into popularity and cultural stature partly as a result of their filmed presence in festivals such as Monterey Pop and Woodstock. These examples demonstrate how moving image and sound recordings of live performances, rather than recordings of studio-produced songs, have served as inciting texts for some of rock's continually venerated figures. Moreover, the experiential aura that filmmakers and sound technicians sought to exhibit via recording devices is not reducible exclusively to music or musician or event. Rather, these commercial documents participate in the festival's contemporaneously credited aims to exemplify the power of collective, peaceful self-organization and freedom, demonstrating a countercultural utopian ideal realized on a mass scale - what the Rolling Stones' tour manager Stanley Booth termed the "festival movement" (2009: web source) and what Simon Frith refers to as events that "provide materially the experience of community that the music expressed symbolically" (1984: 66). Documentaries and live albums made from music festivals of the late1960s have served as containers of what are deemed to be important performances. This service extends to these objects' uses as records of events intended to represent what it may have been like to actually be there, experiencing a moment in rock history. Michael Wadleigh's reflections on Woodstock emphasize his uses of technology towards an experience of the film as an event: "Technology was a means of producing what we felt was going to be a real involving experience" (Woodstock: From Festival to Feature 2009). This faith in technology's ability to reproduce an - or rather the - experience of the event illustrates what is at stake in the relationship of sound and moving image recording. Predicated in terms of fidelity, these intersecting recording practices did not strive simply to capture or represent the event; they created authoritative interpretations of what it was and what it meant.

\section{Means for recording the music festival}

Documentary feature films of live concerts presented unique technical and pragmatic issues in terms of recording popular music events through the cumbersome practice of filmmaking. Heavy filmmaking equipment, the process of capturing sound separately from images, the differences in stage lighting for film exposure and live concert patronage, and the general unpredictability of the concert environment all provided obstacles to filming live music. Thus, technological innovation by record companies, consumer technology companies, and independent filmmakers would prove to be a prerequisite to the very act of capturing such events. For example, Jazz on a Summer's Day (Stern 1960), a film of the 1958 Newport Jazz Festival and an early example of a concert documentary, was spearheaded by Columbia Records's jazz division. The film's funding and organization via Columbia brought with it certain approaches to 
sound recording not common to filmmaking at the time - specifically the production's adoption of high-fidelity monaural analog tape. As detailed by Kier Keightley, record companies' development of high fidelity (or hi-fi) stereo technologies for at-home listener/consumers beginning in the postwar era favored immersion as a key sonic value, a measure of fidelity under the ideal of "transport[ing]" the listener "into the world of music, away from domestic realities" (Keightley 1996: 150). Such concerns would eventually extend to recording live performances for LPs, evident in technicians" pursuits of the "rich and pure" sounds Peck describes in order to realize an experiential quality in the recording, an aural immersion into the space of the concert (Bell 1999: 25).

However, before concert documentaries would regularly produce associated live albums, emerging sound and moving image technologies outside of conventional cinematic practice would govern filmmakers' and technicians' pursuits of fidelity in reproducing concerts for a public, theatrical, cinematic space rather than the space of the home stereo system. The 1964 concert film The T.A.M.I. Show (Binder 1964), for example, was created out of independent producer and media entrepreneur Bill Sargeant's need for a project with which to exhibit the video capture technology of electronovision. Director Steve Binder's intent in using new capture technologies to record musical performances was to allow theatrical audiences to "vicariously be there" as if they were attending a real, live concert (Alpert 2003: web source).

"Being there" was also a stated philosophy of the contemporaneous direct cinema movement, as articulated in the written work of documentarian Richard Leacock $(1997 ; 2012)$. Armed with portable capture technologies that allowed nonfiction filmmakers to record events in real time as they unfolded, practitioners of direct cinema rejected certain staging and storytelling devices of documentary's past - such as direct narration - in favour of an observational mode. Mobilized by Robert Drew and his filmmaking associates including Albert Maysles, D.A. Pennebaker, and Leacock in the making of documentary films for television, what we now often refer to as direct cinema began as a shift in the practice of documentary that sought, in Drew's words, to demonstrate "a dramatic logic in which things really happened" (Drew 2013: web source). While the filmmaking mode took on various forms following Drew's associates' individual projects, direct cinema is generally characterized by filmmakers' cultivation of what Maysles termed a sense of "immediacy" between subject and camera (Vogels 2005: 6). Beyond their adoption of portable, lightweight cameras, documentarians' development of new sound recording techniques was intrinsic to realizing this style. During the early 1960s, Drew's associates augmented their portable $16 \mathrm{~mm}$ Auricon film cameras with a quieter film gauge so that the capturing of events could take place without drawing subjects' attention to the presence of the camera and, even more consequentially, engineered a system whereby the camera was wired to a sync-sound recording device (Mekas 2010: 35; Bailey 2013: web source). Although direct cinema did not initially form around an interest in recording musical subjects, the movement's adaptable approach to camerawork and sound recording would eventually prove vital to realizing dynamic sound and moving image representations of music festivals. 


\section{Music festival documentaries and live albums}

\section{Monterey Pop Festival}

The International Monterey Pop Festival was organized by The Mamas and the Papas' John Phillips, music manager Lou Adler, music producer Alan Pariser, and publicist Derek Taylor towards two specific ends: 1) to create an event that recognized California as an epicenter of youth and music culture, and 2) to produce for rock what the Monterey County Fairgrounds had previously accomplished for jazz and folk music - that is, to elevate rock music as an art form (Koop 2011: web source). Taking place south of San Francisco and incorporating numerous acts associated with the Haight-Ashbury scene over 1618 June, 1967, during what is now commonly known as the Summer of Love, The International Monterey Pop Festival sought to stage a peaceful countercultural gathering, avoiding the possibility of conflict potent in large festivals by providing, in Adler's words, "the best of everything" for performers and attendees, including state-of-the-art sound equipment (Music Festivals 2015: web source). The newly formed Leacock-Pennebaker Productions was commissioned by ABC television to capture the event. $A B C$ would later reject the film after declaring that it did not meet "industry standards" (Beattie 2011: 41), leaving Leacock-Pennebaker paying ABC in order to self-distribute Monterey Pop (Pennebaker 1968). However, the film's protracted circulation did not prevent its wide influence. Monterey Pop's use of mobile filmmaking and sound recording technologies, combined with its kinetic visual style and juxtaposition of onstage acts with images of festivalgoers, would presage the technological and textual design of rock festival documentaries that followed. Additionally, it drew the attention of festival organizers, talent managers, and musical acts looking for ancillary means to profit from one-time live events.

Monterey Pop helped popularize emergent techniques of live concert recording. The film crew recorded sound using their mobile $16 \mathrm{~mm}$ film cameras via an in-camera double system recording process developed by Pennebaker that allowed sound to be recorded synchronously with the image. As summarized by Keith Beattie, this adaptive sound-on-film recording process was accompanied by the capturing of stage and spectator sound via "a second eight-track stereo recorder [that] was linked to a microphone facing the audience to record audience sound", with recording managed by engineer Wally Heider via his mobile studio during the festival (Beattie 2011: 42; Lovece 1986: web source). Heider's influence on such recording techniques is considerable, having popularized the use of remote trucks as mobile studios that house multitrack recording equipment into which the live music is fed and recorded via splitters in concert microphones (McCullaugh 1980: 90). While such techniques were hardly introduced at the 1967 festival, Monterey Pop represents an inciting moment in utilizing remote recording techniques for a feature film's audio track, and several subsequent concert films employed such practices, often by hiring Heider himself.

While no comprehensive official soundtrack for Monterey Pop was released, Heider's recordings of performances by The Jimi Hendrix Experience and Otis Redding were adapted to a LP titled Historic Performances Recorded at the Monterey International Pop Festival (Reprise 1970). Although Monterey Pop only features two songs by each of these performers, Historic Performances... features 
Redding's entire five-song set and four titles of Hendrix's nine-song set, with each side of the record divided between each performer. Released in August 1970, more than three years after Redding's and Hendrix's performances, this live album perpetuates the historical reputation that Monterey Pop had accrued in the intervening years as an important moment in rock music festivals. The copy on the album's back cover reads,

The music, the community feeling and the heady sense of good will which the event radiated became an international social landmark which stood unmatched until two years later when it was joined by Woodstock, the East Coast reflection - somewhat magnified - of Monterey. (Johnson 1970)

As Redding passed away in a plane crash six months after his performance and Monterey introduced Hendrix to a larger audience, the release operates as a vibrant annal of a previous era when, in the album's opening moments, Redding is introduced to a cheering crowd by a festival announcer. The album's function as a historicizing commodity built upon the event's reputation (itself augmented by Pennebaker's film) and was echoed in its reception. For example, Jeffrey Drucker's Rolling Stone review summarizes the release's nostalgic quality by concluding, "memories are made of sets like this" (Drucker 1970: web source).

The live album's artwork further communicates its representational fidelity to the event. Images of these two performances, photographed by Jim Marshall, were assembled in a collage of color stills on the front cover and black-and-white images on the back cover, with the former appearing remarkably similar to the moving images of these performers on display in Monterey Pop. Marshall's stated philosophy of photography echoes the documentary practices espoused by direct cinema, which the photographer once summarized as such: "When I'm photographing people, I don't like to give any direction... I react to my subject in their environment, and if it's going well, I get so immersed in it that I become one with the camera" (quoted in Sisario 2010). Marshall's resistance to directing his still-image subjects rests compatible with Pennebaker's practices of observational distance, realizing a consistent visual language meant to communicate a sense of immediacy and presence through capture and representation. This release illustrates how technological practices of fidelity in sound recording can be supported by aesthetic practices in visual documentation.

\section{Woodstock}

As one of few music festival documentaries of this era to be promoted and released through the full support of a major Hollywood studio, The Woodstock Music and Arts Festival's feature documentary and associated soundtrack/live album would enjoy a more proximate release than the historical distance evident in Monterey Pop and Historic Performances... However, the Woodstock film project did not benefit from Hollywood-scale production value during its initial filming, and its crew was prompted to engage in improvisatory filmmaking techniques in order to adapt to and integrate themselves within an unpredictable festival setting. One of the production's updates of music documentary practice was its combined use of field recording and remote recording, enabled by the 
production's employment of new sound recording technologies separate from, but as portable as the cameras they accompanied, including the Swiss Nagra III discussed at the opening of this article.

While Wadleigh was not a direct affiliate of Drew's direct cinema movement, his work as a director and cinematographer in the late 1960s on films such as the direct cinema parody David Holzman's Diary (McBride 1967) and the portrait of the jazz musician Mingus: Charlie Mingus 1968 (Reichman 1968) established Wadleigh and his New York City-based collaborators as contemporaries of brothers Albert and David Maysles, Pennebaker, and others: a documentarian broadly invested in the possibilities of what insights new media technologies could reveal about cinematic subjects. Wadleigh's Sidewalks of New England (1968), a CBS television special about Aretha Franklin, used the Éclair and Swiss Nagra III to show Franklin performing in concert, edited with innovative splitscreen techniques. With the technical accomplishments of this production, Wadleigh reportedly beat out the Maysles brothers and Pennebaker for the job of filming Woodstock (Bell 1999: 32). Such techniques proved advantageous in convincing Woodstock Ventures that the crew could feasibly capture a sprawling event, and became essential in their adaptation to the difficult circumstances of making the film. Weather created both an obstacle and a subject of Woodstock's troubled production. The rainfall that took over Woodstock and turned a Bethel, New York farm into a pastoral site of mud-caked countercultural collectivism posed serious problems in filming, causing "power surges in the electricity" which knocked out the motors on eight cameras and increased the likelihood of camera operators becoming shocked by their equipment (Bell 1999: 13). Woodstock employed portable filmmaking technologies in order to communicate an intimate, immediate experience of the festival, but such devices ultimately constituted a necessity given the inherent difficulties of making a film about a music festival where everything from the construction of the stage to the elements of outdoor shooting made the space into something far from a controlled film set.

The integrated practice of film sound and live album recording posed similar challenges. Eddie Kramer, a sound recording engineer recruited by Wadleigh as the film's location music engineer in part because he had previously worked with Jimi Hendrix, has reflected on the experience of Woodstock as chaotic, presenting numerous problems that one would largely not encounter within the soundproof walls of a recording studio. Located behind the stage in a "tractor-trailer", Kramer worked on a console with, in his words,

twelve inputs and two little Shure mixers stacked one on top of the other. We had the one eight-track one-inch machine, plus another one in a kind of like an orange crate just sort of held there by a couple of wires - literally hanging on by a thread. (Hobson 2004: web source)

Kramer and engineer Lee Osborne's eight-track recording was later mixed with the documentary's field recordings via the Swiss Nagra III at New York's Record Plant studios for the film's LP soundtrack, titled Woodstock: Music from the Original Soundtrack and More (Cotillion 1970), which combines the sounds of stage music and crowd noise. For this release, Kramer and Osborne are credited 
for location recording alongside "field recording" by the "sound crews of Wadleigh-Maurice, Ltd.", Wadleigh's production company.

Woodstock's approach to representing the music festival via the moving image differed from Monterey Pop in that it intermittently breaks up musical performances with direct interviews with attendees and footage of festival organizers speaking to media, making announcements to the crowd, and fielding technical difficulties brought forth by rainfall. While no direct interviews were adapted to the film's first soundtrack release, the album juxtaposes musical performances with PA announcements and crowd noises. This creates for listeners an audio experience intended to convey the aural space of the festival and imbues a sense of presence by refusing to restrict the soundtrack album to musical performances alone. One illustrative instance of this ambient sound occurs after Joe Cocker's cover (1970) of the Beatles' "With a Little Help from My Friends" (1967) on side three, which is followed by what the track listing describes as "Rainstorm, Crowd Sounds, Announcements \& General Hysteria" (Woodstock $1970 b)$ that conclude the record side. On side four, before Santana's "Soul Sacrifice", the album continues its audio record of rain at Woodstock, focusing for two-and-a-half minutes on a primal "Rain Chant" (Woodstock 1970a) shared amongst a crowd of festivalgoers. Bookended by audio of individual performances, this track evokes an improvisatory offstage musical performance amongst attendees, further emphasizing for the listener a sense of being there, in the space of Woodstock. Rather than isolating the soundtrack's audio to recordings of musical performances engineered by Kramer and Osborne, the film

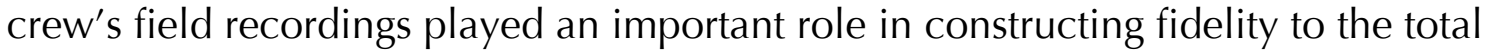
space of the festival.

The Woodstock soundtrack formed an essential component of the promotional push for the film by Warner Bros. Central to Warner's promotional strategy was the studio's plan to release a soundtrack album mastered from the film's audio recording that "should be backed by a big-budget promotional campaign, coinciding with the film campaign" (Undated plans for Woodstock promotion circa 1970). Released two weeks before the film by Atlantic Records' Cotillion label (traditionally used for blues and soul releases), the soundtrack album matched the film's epic and seemingly comprehensive interpretation of the event by spanning three LPs. In order to promote continuous play on record changer turntables, side one shares a record with side six, as with sides two and five and sides three and four, thereby encouraging listeners to experience the soundtrack to completion without interruption, as a continuous event. The release was marked as a soundtrack to the film of the event, not a recording of the event itself, and was thus designed to promote Woodstock rather than evoke the status of an audio record of Woodstock. However, the release was variously received as a soundtrack and a live album. Critic Robert Christgau described the LP set as a "live album" of the festival rather than a soundtrack to a film about the festival (Christgau 1970a: web source). Despite the fact that the Woodstock soundtrack neither perfectly matched the musical and social content of the three-hour film nor provided a strictly linear account of Woodstock itself, the album was promoted to listeners as a credible record of the live event because of its emphasis on evoking a total aural experience of Woodstock - mixing PA announcements 
and crowd activities with music - within an organization of record sides that encouraged continuous play.

\section{Toronto Rock and Roll Revival}

Just as Monterey Pop and its live album demonstrate how certain publicized performances and their mediated representations shape the legacy of a festival, musicians' preferences regarding their recorded representation on celluloid and vinyl could similarly shape cultural memory of a festival. Such forces were very much at play at The Toronto Rock and Roll Revival on 13 September 1969. The event was designed to appeal to the growing cultural nostalgia for midcentury rock'n'roll acts and styles of music, a phenomenon evident in the contemporaneous popularity of 1950s cover band Sha $\mathrm{Na} \mathrm{Na}$ (who performed at Woodstock) and Elvis Presley's return to live performance. However, faced with poor advance ticket sales and knowing that festival films purported a profitable moving image substitute to the central draw of such events, festival organizer John Brower reached out to two individuals in order to amplify the event's commercial prospects both in attendance and ancillary revenue: first D.A. Pennebaker, then John Lennon. Where they had a week to prepare filming Monterey Pop, the filmmakers and crew of Leacock-Pennebaker initiated onsite pre-production in Toronto only a day before the revival began, and the sudden news of Lennon's return to concert performance in the form of the Plastic Ono Band put the film's production into further jeopardy. According to Christgau, one representative of Brower argued to Pennebaker that "John and Yoko had increased the value of Leacock-Penenbaker's film immeasurably and that hence Leacock-Pennebaker should pay the travel expenses of their entourage" (1970b: web source). Dizzying financial disagreements ensued between Brower, Lennon, and LeacockPennebaker, briefly putting the project to a stop before it even began. Live performance, and the question of who wields control over its representation, grew into a subject of significant concern and deliberation in the economic arrangements amongst festival organizers, documentary crews, and performers.

These issues resolved as Leacock-Pennebaker agreed that the Plastic Ono Band could use the sound of the performance captured by the crew for a live album release (Beattie 2011: 35). Thus, Lennon and Ono saw to the production and distribution of an LP of their set titled Live Peace in Toronto 1969 (Apple 1969). Although its mix was sourced from audio recorded by the Leacock-Pennebaker team, no credit is made on the album's sleeve to the fact that it is technically the byproduct of a film project. Lennon mixed the album from the eight-track recording by Pennebaker's crew - the result of an on-site process overseen by Heider similar to his collaboration with Pennebaker for Monterey Pop - at London's Abbey Road Studios, reportedly minimizing Yoko Ono and Eric Clapton's vocals during the stereo master (Blaney 2005: 38).

Unlike the album release of Hendrix and Redding's Monterey Pop performances, no text is present on Live Peace in Toronto 1969 to situate this performance within its festival context. Rather, the album's presentation is minimalist, with its cover design dominated by the blue negative space of a sky hosting a single cloud; the text on the back cover is mostly limited to the title, song list, group lineup, and copyright information. For those familiar with the 
festival's press coverage, which was dominated by news of Lennon's performance, the album served as a delivery system for a performance so widely publicized that it arguably functioned in place of the festival itself. As a headlining Rolling Stone article by Melinda McCracken indicated shortly following the festival, "rock and roll history was celebrated" in Toronto in two respects: the festival's omnibus of 1950s rock' $n$ 'roll acts, and the making of rock history with Lennon's staged surprise return to live performance, the principal subject of the magazine's interest (McCracken 1969: 1, 6). For the Plastic Ono Band - the project that would define Lennon's initial post-Beatles years - Live Peace in Toronto offered a re-introduction of Lennon outside of the context of the Beatles through the prism of his return to live performance, marking a distinct departure from several years of studio-defined Beatles work.

Live Peace in Toronto 1969 eases the audience into Lennon's identity as a live performer. Side one of the album features the Plastic Ono Band performing several covers from Lennon's formative years as a rock musician such as "Blue Suede Shoes" as well as several of Lennon's more recent hits like "Give Peace a Chance", while side two features two longer avant-garde rock tracks with more pronounced vocal involvement by Ono, ending with a reverberating electric hum after Lennon leaves a guitar onstage next to an amplifier. More than a functional recording of a well-known event, the album serves as evidence of a celebrity musician's power in shaping a festival's greater reception and representation in service of his evolving public identity.

Live Peace in Toronto 1969 was technically the first release of LeacockPennebaker's documentation of The Toronto Rock and Roll Revival, and would prove to be the only widely available commercial release of this project's efforts for almost two decades due to "a dispute ensued with Lennon" over the film's release, for the musician "demanded payment for the footage of the concert performance by The Plastic Ono Band" (Beattie 2011: 35). Although The Toronto Rock and Roll Revival was initially intended to showcase 1950s rock acts, publicity around Lennon's surprise return to live performance reframed the event. And this reframing echoed through the event's documents in the release of a live album and the compromised availability of Pennebaker's footage, evincing the degree to which uses of concert recordings can be determined by celebritysubjects who exercise considerable power in shaping meaning of the event that concert films and live albums ostensibly capture.

\section{Rolling Stones' 1969 American tour}

In contrast to festival documentaries that were arranged by festival organizers, Gimme Shelter (Maysles, Mayles, Zwerin 1970) was a film project initiated by the musicians themselves. The Rolling Stones sought out documentarians Albert and David Maysles to capture their 1969 return to touring after a two-year absence, culminating in their headlining of a free festival at the Altamont Speedway in northern California on 6 December. However, rather than a straightforward project about the Stones mobilized by the Stones, Gimme Shelter became an archive of a key event in 1960s rock history as told largely through the band's perspective after four concertgoers were killed at Altamont, including Meredith Hunter, who is visible in the crew's footage being stabbed repeatedly by a 
member of the Hell's Angels. As a result of this tragic event and the legal fallout that followed, the Rolling Stones were reluctant to release a film that represented a murder that had inspired critics to refer to Altamont as the "end of the 1960s" (see Eisen 1970). According to Albert Maysles, Jagger "could not bring himself to sign the release when the film was finished" (Commentary 2009). In the meantime, in September 1970, the Stones released a live recording of a hybrid collection of their two Madison Square Garden shows that inaugurated the tour titled Get Yer Ya-Ya's Out! The Rolling Stones in Concert (Decca 1970), a work that reinforced the narrative around the band as consummate stage performers outside of the tragedy at Altamont. This release was organized through an agreement with Maysles Films, Inc. that gave then-Stones manager Allen Klein's US-based publishing and licensing company, Gideon Music Inc., the "synchronization rights" to make "sound tracks, recordings and other contrivances" from the music recorded for the film (Synchronization and Performing Rights License 1970). Thus, in legal - but not in advertising - terms, this release constituted a soundtrack to the film project. Although a similar Indemnification Agreement also stipulates the group's right to produce a soundtrack album from sound recordings made from Altamont, such documents housed in Columbia University's Rare Books and Manuscripts Library show these contract stipulations crossed out, perhaps suggesting the preference of someone affiliated with the band to not produce a soundtrack of Altamont as such a decision would likely be received as exploiting a tragic event (Indemnification Agreement 1970).

Released three months before Gimme Shelter's December 1970 debut, Get Yer Ya-Ya's Out! distinctly contrasts the foreboding mood that permeates Gimme Shelter, a film structured as an investigative postmortem of the events surrounding Hunter's murder. The album combines audio recordings of the Rolling Stones' two Madison Square Garden shows on 27 and 28 November 1969. While the album's back cover contains photographs from the shows by Ethan Russell and Dominique Tarle, including one photograph that seems to show Jagger dancing on the edge of a stage a few feet away from someone operating a portable film camera, nothing in the album art or text displays a decisive connection between the music of this live album and the film in which much of this Madison Square Garden performance is visible. This may be related to the fact that Gideon's synchronization rights were requested from Maysles Films in pursuit of a live album that was already in planning before the filmmakers officially agreed to film a feature of the Stones' tour. ${ }^{5}$ But as Jagger endeavored to distance himself from the film following Altamont, Get Yer Ya-Ya's Out! resembles how the Rolling Stones likely would have preferred to remember their tour.

Regardless of its textual presentation, shared labor between filmmaking and live recording went into the production of the album. Glyn Johns, the initial producer for what became the Beatles' Let It Be (Apple 1970), served as the onsite recording engineer for the album and is credited as the sound-mixing engineer for the sixteen-track recording process at Madison Square Garden for the film. After utilizing Heider's remote recording truck at the venue, Johns oversaw the recording and mixing of the album in January and February 1970 at London's Olympic Studios, which reportedly involved re-recording and overdubbing Jagger's vocals and Keith Richards's vocals and guitar (Johns 2014: 72-73). ${ }^{6}$ Get 
Yer Ya-Ya's Out! sold well and portended a restoration of the Rolling Stones' reputation as an exceptional stage presence in the wake of Altamont. In his review of the album, critic Lester Bangs wrote for Rolling Stone, "More than just the soundtrack for a Rolling Stones concert, it's a truly inspired session, as intimate an experience as sitting in while the Stones jam for sheer joy in the basement" (Bangs 1970: web source). Such a response could not imaginably serve a higher compliment for a mass-produced concert album of this era. In describing the record as credibly reproducing "sitting in while the Stones jam", Bangs reinforces the power of the recorded object's seeming fidelity to what the experience of the event is imagined to have been. The fact that such sounds were created through a combination of live remote recording and studio performance speaks to the degree to which fidelity is pursued by musicians and producers under the auspices of an ideal regarding what live events should sound like in experiential terms.

\section{Conclusion}

In his recent, provocatively titled essay, "There Is No Music Industry", Sterne contends that traditional interpretations of the term "music industry" offer "a limited way to understand how media industries and music interact", overlooking the ever-changing and extensive relationship between music and heterogeneous forces of industry, technology, and media (Sterne 2014: web source). As illustrated by the role of documentary filmmaking in mobilizing and intersecting with recording practices for live albums, even the more conventional sites of labor from which a commodity-based understanding of "music industry" emerges - that is, commercial recording and live performance - can involve extensive multimedia practices. As this study demonstrates, documentaries have served as ancillary platforms for the business of popular music, provided a formative site of popular music production and recording, and have thereby participated in producing images and sounds that communicate liveness in rock. Liveness, I argue, has never been a fixed quality in popular music history, nor have its representations been realized through homogeneous or uniform means. Representational notions of liveness are instead bound by the historically specific contexts, practices, and cultures that produce them. In this respect, examining transmedia technological practices invites a more detailed historical understanding of how cross-industrial and multimodal media labor shapes the value judgments and aesthetic criteria that define popular music cultures. For instance, as several of the above case studies illustrate, notions of authenticity and liveness in rock are not only aural but visual, predicated through claims to truth and authority evident in feature films, album art, and the illustrative language of publicity. Moving image production has taken more than an accessory role in communicating values of liveness in popular music - it has structured practices of recording and participated in standards of representation through various activities of media labor. And the space of the music festival is a rich, revelatory site of rock history in which these media industries and practices converged. 


\section{Acknowledgements}

The author expresses his appreciation to Dr. Craig Eley, the issue editors, and the anonymous reviewers for their valuable feedback and suggestions in the formation of this article.

\section{Endnotes}

1 As Gracyk demonstrates, "recording's status as a distinct medium is not unique to rock", citing musique concrète as an example (Gracyk 1996: 42).

2 Sound City ends with director and Foo Fighters lead Dave Grohl moving the recording technologies from the defunct Los Angeles-based recording studio Sound City to his home as something of a nostalgic shrine to analog recording practices. See also: Meintjes 2012.

${ }^{3}$ For a history of live musical performance of rock on television, see Forman 2012: 319339.

${ }^{4}$ My methodology is informed by Sterne's consideration of "sound events in terms of their own social and cultural location", for such an approach illustrates into relief sound fidelity's functions "as an operative concept, a technical principle, and an aesthetic" informed by "a history of beliefs in and about sound reproduction as well as a history of the apparatuses themselves" (Sterne 2003: 221).

${ }^{5}$ Gimme Shelter opens with the Rolling Stones subjected to a photo shoot in Birmingham, UK for possible images for the forthcoming live album. However, no images from this session were used for the cover.

${ }^{6}$ Overdubbing refers to the process of overlaying a new recording on top (rather than in place) of an existing recording, thereby creating a layered effect, typically but not exclusively pertaining to vocals.

\section{References}

\section{Bibliography}

Alpert, N. 2003. 2003 Interview with Steve Binder, Director of The T.A.M.I. Show. High Frequencies. http://high-frequencies.tumblr.com/TAMI_SHOW; Accessed: 6 December 2015.

Altman, R. 1992. Introduction: Four and a Half Film Fallacies. In R. Altman Ed. Sound Theory Sound Practice. New York: Routledge: 35-45.

Auslander, P. 2008. Liveness: Performance in a Mediatized Culture. New York: Routledge. Second edition.

Bailey, J. 2013. The Camera(s) that Changed the World. The American Society of Cinematographers. 9 September. http://www.theasc.com/site/blog/johnsbailiwick/the-cameras-that-changed-the-world/; Accessed: 6 December 2015.

Bangs, L. 1970. Get Yer Ya-Ya's Out. Rolling Stone. 4 September. http://www.rollingstone.com/music/albumreviews/get-yer-ya-yas-out19701112; Accessed: 14 March 2016.

Beattie, K. - 
2008. Documentary Display. New York: Wallflower Press.

2011. D.A. Pennebaker. Champaign, IL: University of Illinois Press.

Bell, D. 1999. Woodstock: An Inside Look at the Movie that Shook Up the World and Defined a Generation. Studio City, CA: Michael Wiese Productions.

Blaney, J. 2005. John Lennon: Listen to This Book. Guildford: Paper Jukebox.

Booth, S. 2009. Gimme Shelter: The True Adventures of Altamont. Criterion. 1

December. https://www.criterion.com/current/posts/104-gimme-shelter-thetrue-adventures-of-altamont; Accessed: 23 November 2015.

Christgau, R. -

1970a. Consumer Guide Album: Woodstock. Robert Christgau: Dean of American Rock Critics.

http://www.robertchristgau.com/get_album.php?id=8166; Accessed: 14 March 2016.

1970b. Toronto Rock \& Roll Revival 1969. Show. January. Robert Christgau: Dean of American Rock Critics.

www.robertchristgau.com/xg/music/toronto-69.php; Accessed: 6

December 2015.

Drucker, J. 1970. Historic Performances Recorded at the Monterey International Pop Festival. Rolling Stone 15 October.

http://www.rollingstone.com/music/albumreviews/historic-performancesrecorded-at-the-monterey-international-pop-festival-19701015; Accessed: 14 March 2016.

Dwyer, M.D. 2015. Back to the Fifties: Nostalgia, Hollywood Film, and Popular Music of the Seventies and Eighties. New York: Oxford University Press.

Eisen, J. 1970. Altamont: Death of Innocence in the Woodstock Nation. New York: Avon.

Forman, M. 2012. One Night on TV is Worth Weeks at The Paramount: Popular Music on Early Television. Durham, NC: Duke University Press.

Frith, S. -

1984. Rock and the Politics of Memory. Social Text 9/10 (Spring-

Summer): 59-69.

2007. Live Music Matters. Scottish Music Review 1(1): 1-17. http://www.scottishmusicreview.org/index.php/smr/article/view/9/8

2010. Analysing Live Music in the UK: Findings One Year into a ThreeYear Research Project. Journal of the International Association for the Study of Popular Music 1(1): 1-30.

Frith, S., Brenna, M., Cloonan, M. and Webster, E. 2013. The History of Live Music in Britain, Vol. 1: 1950-1967. Aldershot: Ashgate.

Gracyk, T. 1996. Rhythm and Noise: An Aesthetics of Rock. London: I.B. Taurus. Hobson, M. 2004. Eddie Kramer - Woodstock Interview. Acoustic Sounds News. 18 August 2004. http://news.acousticsounds.com/post.cfm/eddie-kramerwoodstock-interview; Accessed: 14 March 2016.

Indemnification Agreement. 1970. Columbia University Rare Books and Manuscripts Library. Maysles Collection. Box 60. "Synchronization and Performing Rights License" Folder.

Johns, G. 2014. Sound Man: A Life Recording with the Rolling Stones, The Who, Led Zeppelin, The Eagles, Eric Clapton, the Faces... New York: Plume. 
Johnson, P. 1970. Historic Performances Recorded at the Monterey International Pop Festival. Reprise Records. LP liner notes.

Kahana, J. 2008. Intelligence Work: The Politics of American Documentary. New York: Columbia University Press.

Keightley, K. 1996. "Turn It Down! » She Shrieked: Gender, Domestic Space, and High Fidelity, 1948-59. Popular Music 15(2): 149-177.

Koop, B. 2011. Looking Back at Monterey Pop. MusoScribe. 28 October. http://blog.musoscribe.com/index.php/2011/10/28/looking-back-at-montereypop/; Accessed: 6 December 2015.

Lastra, J. 2000. Sound Technology and the American Cinema: Perception, Representation, Modernity. New York: Columbia University Press.

Leacock, R. -

1997. A Search for the Feeling of Being There. Richard Leacock. 20 May. http://richardleacock.com/A-Search-for-the-Feeling-of-Being-There; Accessed: 24 November 2015.

2012. The Feeling of Being There: A Filmmaker's Memoir. Paris: Semeoin.

Lovece, F. 1986. "Monterey Pop" Vid Transfer No Easy Job. Billboard. 22 March. Archived via Scribd: http://www.scribd.com/doc/149392592/Monterey-Pophome-video-D-A-Pennebaker-interview; Accessed: 6 December 2015.

McCullaugh, J. 1980. High Tech Times in the World's Recording Mecca. Billboard 92(46), 15 November: 90.

McCracken, M. 1969. Rock and Roll Revival Surprise: John and Yoko. Rolling Stone. 18 October.

McKinna, D.R. (2014), The Touring Musician: Repetition and Authenticity in performance. Journal of the International Association for the Study of Popular Music 4(1): 56-72.

Meintjes, L. 2012. The Recording Studio as Fetish. In J. Sterne Ed. Sound Studies Reader. London: Routledge: 266-273.

Mekas, J. 2010. An Interview with the Maysles Brothers. In K. Beattie Ed. Albert \& David Maysles Interviews. Jackson, MS: University Press of Mississippi: 33-37.

Music Festivals: An Overview of the Australian Scene, 1970-75. MILESAGO: Australasian Music and Popular Culture 1964-1975. http://www.milesago.com/Festivals/intro.htm; Accessed: 6 December 2015.

Saunders, D. 2007. Direct Cinema: Observational Documentary and the Politics of the Sixties. London: Wallflower Press.

Sisario, B. 2010. Jim Marshall, Rock ' $n$ ' Roll Photographer, Dies at 74. The New York Times. 24 March.

http://www.nytimes.com/2010/03/25/arts/music/25marshall.html; Accessed: 14 March 2016.

Sterne, J. -

2003. The Audible Past: Cultural Origins of Sound Reproduction. Durham, NC: Duke University Press.

2014. There Is No Music Industry. Media Industries 1(1): 50-55.

http://www.mediaindustriesjournal.org/index.php/mij/article/view/17/75

Synchronization and Performing Rights License. 1970. Columbia University Rare Books and Manuscripts Library. Maysles Collection. Box 60. "Synchronization and Performing Rights License" Folder. 
Théberge, P. 1997. Any Sound You Can Imagine: Making Music/Consuming

Technology. Hanover, CT: Wesleyan University Press.

Thornton, S. 1996. Club Cultures: Music, Media, and Subcultural Capital.

Hanover, CT: Wesleyan University Press.

Toynbee, J. 2000. Making Popular Music: Musicians, Creativity and Institutions. London: Arnold.

Undated plans for Woodstock promotion. circa 1970. The Margaret Herrick Library at the Academy of Motion Picture Arts and Sciences. Marty Weiser Papers.

Vogels, J.B. 2005. The Direct Cinema of David and Albert Maysles. Carbondale, IL: Southern Illinois University Press.

Discography

Plastic Ono Band, the. 1969. Live Peace in Toronto 1969. Apple, UK.

Woodstock -

1970a. "Rain Chant". Woodstock: Music from the Original Soundtrack and More, Cotillion, US.

1970b. "Rainstorm, Crowd Sounds, Announcements \& General Hysteria". Woodstock: Music from the Original Soundtrack and More, Cotillion, US.

Redding, Otis and The Jimi Hendrix Experience. 1970. Historic Performances Recorded at the Monterey International Pop Festival. Reprise, US.

Rolling Stones, the. 1970. Get Yer Ya-Ya's Out! The Rolling Stones in Concert. Decca, UK.

Various. 1970. Woodstock: Music from the Original Soundtrack and More. Cotillion, US

Videography

Commentary. 2009. Gimme Shelter. Criterion. Blu-ray.

Drew, J. 2013. Filmmaker Robert Drew Discusses His Ideas That Created American Cinema Verite (1962). Vimeo. https://vimeo.com/84270680; Accessed: 2 December 2015.

Gimme Shelter. 1970. Dir. Albert Maysles, David Maysles, Charlotte Zwerin, Maysles Films, Inc.

Jazz on a Summer's Day. 1960. Dir. Burt Stern, New Yorker Films. Monterey Pop. 1968. Dir. D.A. Pennebaker, Leacock-Pennebaker.

Soundbreaking. 2016. Soundbreaking Trailer. YouTube.

https://www.youtube.com/watch?v=hUdPVdLK8MQ\&feature=youtu.be; Accessed: 14 March 2016.

Sound City. 2013. Dir. David Grohl, Variance Films/Roswell Films/Gravitas Ventures.

T.A.M.I. Show, The. 1964. Dir. Steve Binder, American International Pictures. Woodstock: From Festival to Feature. 2009. Special feature on Woodstock: Three Days of Peace and Music. Warner Bros. Home Video, Blu-ray. 
Woodstock: Three Days of Peace and Music. 1970. Dir. Michael Wadleigh, Warner Bros. 